\title{
A Classification of Landscape Services to Support Local Landscape Planning
}

\author{
María Vallés-Planells $^{1}$, Francisco Galiana $^{1}$ and $^{\text {Veerle Van Eetvelde }}{ }^{2}$
}

\begin{abstract}
The ecosystem services approach has been proven successful to measure the contributions of nature and greenery to human well-being. Ecosystems have an effect on quality of life, but landscapes also, as a broader concept, may contribute to people's well-being. The concept of landscape services, compared to ecosystem services, involves the social dimension of landscape and the spatial pattern resulting from both natural and human processes in the provision of benefits for human-well being. Our aim is to develop a classification for landscape services. The proposed typology of services is built on the Common International Classification of Ecosystem Services (CICES) and on a critical review of existing literature on human well-being dimensions, existing ecosystem service classifications, and landscape perception. Three themes of landscape services are defined, each divided into several groups: provisioning, regulation and maintenance, cultural and social life fulfillment, with the latter focusing on health, enjoyment, and personal and social fulfillment. A special emphasis is made on cultural services, which are especially important when applied to landscape and which have received less attention.
\end{abstract}

Key Words: cultural services; ecosystem services; holism; landscape services; spatial pattern; transdiciplinarity

\section{INTRODUCTION}

The ecosystem services (ES) framework emerged in the context of the concerns raised about the serious threats posed by the existing pace of human transformations of natural ecosystems. At the end of the 20th century, it is realized that natural resources are fundamental to the existence of humanity. Their disruption and exploitation are reaching a scale that could compromise human well-being (Brundtland 1987). In this context, ecosystem services characterize the ways in which natural ecosystems confer benefits on humanity and allow environmental functions to be included in economic valuation procedures (de Groot 1992, Costanza et al. 1997, Daily 1997).

The ES framework has been applied mostly to natural areas, but also to agricultural (Björklund et al. 1999, Macfadyen et al. 2012) and urban areas (Dobbs et al. 2011, Gómez-Baggethun and Barton 2013). However, the emphasis was mainly on the benefits of the existing nature within these areas. This is because the concept of ecosystem services was originally linked to the role of nature in human well-being, and human action was conceived as the cause of the alteration of ecosystems. However, since the beginning of the 21st century, additional approaches have appeared on the international agenda, e.g., European Landscape Convention (Council of Europe 2000), Convention for the Safeguarding of the Intangible Cultural Heritage (UNESCO 2003), and the Convention on the Value of Cultural Heritage for Society (Council of Europe 2005). Landscape, cultural identity, and diversity, shaped by the way people have interacted with nature through history, are recognized as important components of sustainable development and human well-being.

Previous works have shown that not only do landscape elements by themselves have an influence on the provision of benefits, but so do their contexts, the relationships between them, and their spatial arrangements (Blaschke 2006). Cottrell et al. (2005) showed how different configurations of green spaces were associated with different types of experiences. Shafer et al. (2000) related greenways to different use patterns according to their location and design. Nohl (2001) suggested that the ability of landscapes to deliver orientation patterns can be lost, not just because of the removal of landmarks, but because they have become ineffective.

Landscape, as defined in the European Landscape Convention (Council of Europe 2000), is a holistic, spatial, and mental dynamic entity, which is the result of people-place interactions (Antrop 2000, Tress and Tress 2001, Antrop et al. 2012). A holistic view implies the hierarchical organization of landscape, and the context of and relationship between the landscape elements. Its dual dimension, material and immaterial, implies that landscape is not just a geographical entity composed of abiotic, biotic, and human-made elements, but it is also our perceived environment.

The consideration of this perceptual aspect involves a different concept of the role of human beings when compared with the conventional ecological approach. Humans are not just seen as factors whose actions have a positive or negative impact on nature; they are seen as an integral part of the landscape. This means that landscapes are the result of the interaction between natural and human processes. People have influenced landscapes throughout time to adapt it to their changing demands, and at the same time, landscapes have influenced people. This landscape concept is grounded on the total human ecosystem (THE) concept, which involves an additional integration level above natural ecosystems in which humans are integrated within their total environment (Naveh and Lieberman 1994, Naveh 2000).

In accordance with this transdisciplinary and integrated concept of landscape, Termorshuizen and Opdam (2009) suggested that the concept of 'landscape services' would be more appropriate than 'ecosystem services' to enable the incorporation of both natural and cultural aspects, the consideration of spatial patterns, and the involvement of stakeholders, especially in the context of local collaborative landscape planning. In their approach, landscape was not considered a synonym for ecosystem (e.g. de Groot 2006) or not considered to be a group of ecosystems, but landscapes were seen as spatial human-ecological systems, which

${ }^{1}$ Universitat Politècnica de València, Departamento de Ciencia Animal, Grupo de Acuicultura y Medio Ambiente, ${ }^{2}$ Ghent University, Department of Geography 
delivered a wide range of functions valued by humans for economic, socio-cultural, and ecological reasons.

Consequently, the application of the landscape services concept to collaborative landscape planning requires the consideration of additional issues when compared to the ecosystem services approach. With regard to the typology of services, our focus, there should be a balance between the material and immaterial benefits of landscape perceived by local communities; between well-being gains derived from nature and from the interaction of nature with humans; and between the vertical and horizontal relations of landscape. We aim to develop a classification of landscape services that is consistent with the integrated concept of landscape and its application to landscape planning. Our proposed classification of landscape services adapts the Common International Classification for Ecosystem Services (CICES; Haines-Young and Potschin 2010) to the meaning of landscape services and integrates those aspects that are inherent to landscape.

\section{THEORETICAL BACKGROUND}

Ecosystem services classifications and the Common International Classification for Ecosystem Services (CICES)

Previous reviews on the ecosystem services approach (Hermann et al. 2011, Lamarque et al. 2011) have shown a wide range of ecosystem services' classifications. These classifications differed on the typology of services and on the meaning of the key terms, i.e., process, function, service, and benefit. With regard to the services considered, most of the classifications (Constanza 1997, MEA 2003, de Groot et al. 2010, TEEB 2010) included services that affect human well-being both directly or indirectly, whereas others questioned the validity of considering those services that do not directly benefit humans, i.e., water regulation or pollination (Wallace 2007). There is also a lack of consensus in the meaning of function. For some (Constanza 1997, MEA 2003, Wallace 2007), 'function' is synonymous with 'ecosystem process, 'whereas for others, 'function' means the capacity of ecosystems to provide goods and services (de Groot 2006, de Groot et al. 2002, 2010). Function becomes a service when humans enjoy it. Bolliger and Kienast (2010) weighed in on the debate by stating that services depend on the capacity of the ecosystems and on the demands of the people. In our vision, the concept of benefit is separated from ecosystem services because human benefits are understood as the product of natural and other forms of capital (Lamarque et al. 2011), whereas ecosystem services are solely derived from natural capital.

Haines-Young and Potschin (2010) developed a classification for ES, Common International Classification for Ecosystem Services (CICES), a very valuable work, which compiled existing approaches along with the main key terms. The CICES classification has three categories of services: (1) provisioning, (2) regulation/maintenance, and (3) cultural. These services are related to three types of functions: resource, sink, and service. Regarding the key terms, a distinction is made between 'process, ' 'function,' 'service,' and 'benefit.' 'Functions' are considered as an intermediate concept between 'processes' and 'services.' Functions are defined as the capacity of ecosystems to provide services and benefits to human users, whereas services are assumed to depend on the existence of beneficiaries. Services are defined as the direct and indirect contributions to human welfare, whereas benefits are considered to be the welfare gains derived from ecosystems (Haines-Young and Potschin 2010). The effort of integration in CICES classification makes it an interesting starting point for applying the concept of landscape services. However, it is necessary to consider additional issues if the concept of landscape services is to be applied in landscape planning and design.

First, within the provisioning services, only the role of landscape as a provider of natural resources is included in CICES. The concept of landscape as an arena or a place that supports people's daily activities is lacking, despite the reference to humans within CICES service functions: "which provide the habitat for all living beings including mankind" (Haines-Young and Potschin 2010:4). This aspect, i.e., landscape as the scenery of our daily activities, can be also related to the carrier functions defined by de Groot (2006), who refered to the capacity of ecosystems to provide space and a suitable substrate (soil) or medium (water, air) to support human activities such as cultivation, habitation or transportation, and to the provision of space, i.e., providing suitable living space (Antrop et al. 2012). Some of these carrier functions, such as cultivation and energy conversion, are already included in CICES classification, but others, related to habitation or transportation, are not present. According to de Groot (2006:178): "The sustainability criterion excludes the use of most of the so-called carrier functions in natural and semi-natural systems since they, by definition, involve the conversion of the original ecosystem into another type of land use involving permanent conversion of the original ecosystem." Because landscape also includes humanmade environments, these functions should be considered.

Second, in CICES classification, regulating services focus on the capacity to control ecological processes within an ecosystem level, i.e., vertical relations. The services are centered on the interactions between abiotic and biotic components within ecosystems. For instance, vegetation has an effect on water infiltration processes, which, in turn, condition water flow regulation services. However, when applying this concept to landscapes, two additional issues should be considered: the regulation of both perceptual and ecological processes, and the role of the horizontal relationships among ecosystems, at the landscape scale, in regulating both types of processes.

Third, CICES classification (Bolliger and Kienast 2010) has a bias toward provisioning and regulating services, paying less attention to the cultural services. Cultural services refer to the nonmaterial outputs that people obtain from contact with ecosystems. It acquires special importance because the immaterial dimension is inherent to landscape. In this sense, a classification of landscape services should show a balance between the services related to its material and immaterial or perceptual dimensions. It should acknowledge the role of landscape as a palimpsest and the benefits for immaterial well-being derived from the continuous interactions through time between human societies and their environment. Different authors have suggested that further development is needed for the cultural services (Daniel et al. 2012, Norton et al. 2012), and our research emphasizes this part of the classification.

\section{Ecosystem services and human well-being}

The landscape services concept, like ecosystem services, is linked to human well-being. Hence, the proposal of any additional 
service requires significant relationships between ecosystem and landscape structures and the satisfaction of human needs. However, there is not a universally accepted definition for human well-being. Different disciplines have focused on the study of well-being, psychology and economics being the most relevant in providing theoretical and empirical knowledge. Different terms, i.e., ingredients of the quality of life, basic human needs, elements of the utility vector, aspects of well-being, or universal human values, have been used to refer to the multiple dimensions of human wellbeing. Despite the existing amount of research in the fields of human well-being and ecosystem services, there are only a few projects that focused on analyzing the causal relationships between ecosystem services and the dimensions of well-being (MEA 2003, Wallace 2007, 2012, Summers et al. 2012). These projects went through two different stages: (1) based on well-being literature, they focused on the human perspective and defined people's needs for a good life; and (2) they identified aspects in which the environment could condition these needs.

In MEA (2003), the different categories of ecosystem services, i.e., provisioning, regulating, supporting, and cultural, were linked to five main components of well-being. These were derived from the human development dimensions obtained in the "voices of the poor" research (Narayan et al. 2000). Summers et al. (2012) proposed an alternative classification of the elements of well-being based on Maslow's needs pyramid (Maslow 1970). Wallace (2007, 2012) developed a planning-oriented classification of ecosystem services based on the specific human values the services support. He examined previous work on human needs and values (Maslow 1970, Andrewartha 1971, Rokeach 1973) and on ecosystem services (MEA 2005). When comparing all of these well-being dimensions, certain similarities were inferred. 'Health and security' (MEA 2003) corresponded to both 'environmental well-being' (Summers et al. 2012) and 'health, i.e., physical and chemical environment/ protection from other organisms' (Wallace 2012). 'Basic material for good life' (MEA 2003) was parallel to 'basic human needs' (Summers et al. 2012) and to 'adequate resources' (Wallace 2012). However, there was no clear correspondence among the other dimensions of well-being, which are mainly related to the cultural services.

We propose a rearrangement of the dimensions related to cultural services based on the former three works, i.e., MEA 2003, Summers et al. 2012, and Wallace 2012, and on the review on human wellbeing dimensions conducted by Alkire (2002). The dimensions in question are: health, security, adequate resources, enjoyment, and personal and social fulfillment. Health refers to both physical and mental health. Security involves living in a safe environment in terms of both the natural and human conditions. Adequate resources include having the basic needs covered, i.e., food, shelter, etc. Enjoyment is related to spare time, i.e., play and entertainment, and it corresponds to 'recreation' in Wallace (2012). Enjoyment refers to the need to have a balance between work and leisure. Personal fulfillment involves the self-realization need, or growing as a person. Personal fulfillment is related to 'spiritual and philosophical contentment' in Wallace (2012) and to 'freedom and choice' and 'good social relations' in MEA (2003). Social fulfillment is related to our need to live in close contact with other people, family and friends, or to feel that we are part of a community. Social fulfillment is related to 'socio-political fulfillment' in Wallace (2012) and to 'good social relations' in MEA (2003).
The achievement of these six dimensions and the importance attached to them will depend on the individual characteristics of every person in combination with their social and geographical environment. Their geographical environment is the focus of the ecosystem services approach. Provisioning services are usually linked to adequate resources. Regulating services are related to all the dimensions, especially to ensure safety needs and to prevent natural disasters. Cultural services are mainly connected with enjoyment and personal and social fulfillment. With regards to health, it is generally related to the provisioning and regulating categories, although in our work, we also show its connection to cultural services.

\section{Cultural services and human well-being}

Links between human well-being dimensions and cultural services are identified based on previous classifications and work in environmental psychology. Table 1 compares the types of cultural services considered in ecosystem services classifications (MEA 2005, Research Box et al. 2009, de Groot et al. 2010, HainesYoung and Potschin 2010, TEEB 2010) and their connections with human well-being dimensions.

All the reviewed classifications show the links between ecosystems and both enjoyment and personal fulfillment. Enjoyment is involved in recreation services and related to the role the physical environment plays in people's spare time. The contribution of nature to some aspects of personal fulfillment is assumed when ecosystems are considered as sources of knowledge, inspiration, and spiritual experience (Bernbaum 1991, Lindemann-Matthies 2005, Bos et al. 2008). The categories of services connected to personal fulfillment correspond to learning, historic, cultural, or spiritual social values (Brown 2004), showing the role of environment in making people's lives more fulfilling from an intellectual, transcendental, or artistic point of view. The spatial environment makes additional contributions to personal fulfillment, as suggested by existing research on environmental psychology. The spatial environment plays a role in way-finding, provides information, and satisfies human needs related to understanding and exploration (Lynch 1960, Kaplan et al. 1998).

The connection with health is also considered in previous cultural service classifications, but only in a few works (Research Box et al. 2009, TEEB 2010). The positive effects of nature on psychological and physical well-being have been proven, not just with natural landscapes but also with urban green spaces (Tzoulas and Greening 2011). Contact with nature contributes to stress reduction (Ulrich 1984, Ward Thompson et al. 2012), relaxation and worry reduction and random thoughts (Korpela et al. 2001), recovery from physical illness (Ulrich 1997), or attention restoration (Kaplan and Kaplan 1989). Natural and designed green areas also provide opportunities for physical activity and may increase walking and physical activity patterns (Shafer et al. 2000, Jackson 2003).

The role of outdoor settings in promoting social fulfillment is reflected in the following categories: (1) social relations, (2) heritage-related cultural identity, and (3) sense of place. The first category corresponds to the individual perspective, whereas the second and third refer to the community context. In the literature, we found three ways in which the geographical environment fosters social fulfillment. First, it provides spaces in which social encounters can occur (Matsuoka and Kaplan 2008) separate from 
Table 1. Comparison of typologies of cultural services in different ecosystem service classifications.

\begin{tabular}{|c|c|c|c|c|c|}
\hline \multirow[b]{2}{*}{$\begin{array}{c}\text { Human Well-being } \\
\text { Dimensions }\end{array}$} & \multicolumn{5}{|c|}{ Cultural Service Classifications } \\
\hline & MEA (2003) & $\begin{array}{l}\text { Research Box et al. } \\
\text { (2009) }\end{array}$ & $\begin{array}{c}\text { de Groot et al. } \\
(2010)\end{array}$ & TEEB (2010) & $\begin{array}{l}\text { Haines-Young and } \\
\text { Potschin (2010) }\end{array}$ \\
\hline & Aesthetic values & & Aesthetic & $\begin{array}{c}\text { Aesthetic } \\
\text { appreciation }\end{array}$ & Aesthetic \\
\hline Enjoyment & $\begin{array}{l}\text { Recreation and } \\
\text { ecotourism }\end{array}$ & $\begin{array}{l}\text { Recreation (leisure } \\
\text { and activities) }\end{array}$ & Recreational & $\begin{array}{l}\text { Recreation and } \\
\text { tourism }\end{array}$ & Recreation \\
\hline \multirow[t]{4}{*}{ Personal fulfillment } & Educational values & Learning & $\begin{array}{l}\text { Education and } \\
\text { science }\end{array}$ & & $\begin{array}{l}\text { Information and } \\
\text { knowledge }\end{array}$ \\
\hline & $\begin{array}{l}\text { Knowledge systems } \\
\text { (traditional and } \\
\text { formal) }\end{array}$ & & & & \\
\hline & $\begin{array}{l}\text { Spiritual and } \\
\text { religious values }\end{array}$ & Spiritual & $\begin{array}{l}\text { Spiritual and } \\
\text { religious inspiration }\end{array}$ & Spiritual experience & Spiritual \\
\hline & Inspiration & Inspiration & $\begin{array}{l}\text { Inspiration for } \\
\text { culture, art, and } \\
\text { design }\end{array}$ & $\begin{array}{l}\text { Inspiration for } \\
\text { culture, art, and } \\
\text { design }\end{array}$ & \\
\hline \multirow[t]{2}{*}{ Health } & & Escapism & & $\begin{array}{c}\text { Mental and physical } \\
\text { health }\end{array}$ & \\
\hline & & Calm & & & \\
\hline \multirow[t]{3}{*}{ Social fulfillment } & Social relations & & & & $\begin{array}{l}\text { Community } \\
\text { activities }\end{array}$ \\
\hline & $\begin{array}{l}\text { Cultural heritage } \\
\text { values } \\
\text { Cultural diversity }\end{array}$ & $\begin{array}{l}\text { A sense of history } \\
\text { and continuity }\end{array}$ & $\begin{array}{l}\text { Cultural heritage } \\
\text { and identity }\end{array}$ & & Heritage \\
\hline & Sense of place & A sense of place & & Sense of place & \\
\hline
\end{tabular}

the two usual social environments of home and the workplace. This idea is related to the concept of 'third place' introduced by Oldenburg (2000). Kuo (2003) and Kim and Kaplan (2004) showed the link between urban green spaces and resident interactions. Pendola (2008) proved that 'main street' design affects the sense of community. Second, landscapes can play an important role in shaping the identity of a community or as icons for social open spaces (Hull et al. 1994, Graham et al. 2009). Finally, landscapes can also contribute to creating a sense of material continuity through the life course (Graham et al. 2009). For instance, certain places evoke memories of our childhood and relatives who passed away, and they give us a chance to remember past times, thus providing us with a certain sense of well-being (Antrop 2003).

Concerning aesthetic and heritage values, which have usually been included in previous classifications, they are not considered services in our proposed classification. Instead, they are taken into account as landscape qualities or resources. In this way, aesthetics are seen as a quality of landscape, which can champion recreation or inspiration. Similarly, cultural heritage is considered a landscape resource providing a sense of place, a sense of continuity, or opportunities for researching or learning.

\section{LANDSCAPE SERVICES CLASSIFICATION}

The classification described shows the way in which CICES classification has been adapted to the concept of landscape services (Table 2). Together with the conventional functions used in previous ecosystem services classifications, the regulation of perceptual processes and the provision of space have been considered. Consequently, additional services have been added to the provisioning and regulating categories. However, the main changes are introduced in the cultural group. This category is rearranged to include the different contributions of landscape to human well-being dimensions in a more comprehensive and consistent way.

\section{Provisioning services}

Provisioning services are generally related to the function of ecosystems as sources of natural resources. They provide us with food, water, and energy, essential elements for our survival, which satisfy our basic material needs. However, landscape also deals with other needs. They are not only related to productive activities depending on endogenous resources, e.g., fertile soil, but also to other uses, e.g., infrastructures, residential, or industrial activities, which require a certain space to support them. These activities also contribute to the community well-being. Consequently, in the same way that ecosystems satisfy basic human needs as a source of natural resources, we assume that landscapes, as the scenes of our daily lives, will also provide local communities with a place for developing their basic everyday activities. These basic daily activities are summarized as a place to live, move, and work (Table 3). The inclusion of this class may promote the incorporation of sustainability criteria when planning and designing areas in which people spend most of their time. The provision of services will differ depending on the arrangement of the different land uses and on the interaction between green and grey infrastructure. For instance, certain spatial patterns of 
Table 2. Landscape services classification based on Common International Classification of Ecosystem Services (CICES) classification (Haines-Young and Potschin 2010). New proposed services are indicated in bold.

\begin{tabular}{|c|c|c|}
\hline Theme & Class & Group \\
\hline \multirow[t]{8}{*}{ Provisioning } & Nutrition & $\begin{array}{l}\text { Terrestrial plant and animal foodstuffs } \\
\text { Freshwater plant and animal foodstuffs } \\
\text { Marine plant and animal foodstuffs } \\
\text { Potable water }\end{array}$ \\
\hline & \multirow[t]{2}{*}{ Material } & Biotic materials \\
\hline & & Abiotic materials \\
\hline & \multirow[t]{2}{*}{ Energy } & Renewable biofuels \\
\hline & & Renewable abiotic energy sources \\
\hline & \multirow[t]{3}{*}{ Daily activities } & Place to live \\
\hline & & Place to work \\
\hline & & Place to move \\
\hline \multirow[t]{14}{*}{ Regulation and Maintenance } & \multirow[t]{2}{*}{ Regulation of wastes } & Bioremediation \\
\hline & & Dilution and sequestration \\
\hline & \multirow[t]{3}{*}{ Flow regulation } & Air flow regulation \\
\hline & & Water flow regulation \\
\hline & & Mass flow regulation \\
\hline & \multirow[t]{3}{*}{ Regulation of physical environment } & Atmospheric regulation \\
\hline & & Water quality regulation \\
\hline & & Pedogenesis and soil quality regulation \\
\hline & \multirow[t]{3}{*}{ Regulation of biotic environment } & $\begin{array}{l}\text { Lifecycle maintenance and habitat } \\
\text { protection }\end{array}$ \\
\hline & & Pest and disease control \\
\hline & & Gene pool protection \\
\hline & \multirow[t]{3}{*}{ Regulation of the spatial structure } & Connection of spaces \\
\hline & & Buffer disturbing use \\
\hline & & Provision of spatial complexity of the place \\
\hline \multirow[t]{12}{*}{ Cultural and Social } & \multirow[t]{2}{*}{ Health } & Mental health \\
\hline & & Physical health \\
\hline & \multirow[t]{2}{*}{ Enjoyment } & Passive enjoyment \\
\hline & & Active enjoyment \\
\hline & \multirow[t]{5}{*}{ Self-fulfillment (personal) } & Way-finding \\
\hline & & Scientific resources \\
\hline & & Didactic resources \\
\hline & & Spiritual experience \\
\hline & & Source of inspiration \\
\hline & \multirow[t]{3}{*}{ Social fulfillment } & Social interactions \\
\hline & & Place identity \\
\hline & & Sense of continuity \\
\hline
\end{tabular}

residential land-use growth may indicate that an area behaves solely as a place to live, whereas other physical patterns can also promote climate regulation, recreational opportunities, and social interactions.

\section{Regulating and maintenance services}

In the presented classification, regulating and maintenance services included how ecosystems controlled or modified the ecological and perceptual aspects of landscape. According to de Groot (2006), regulation services are considered a necessary precondition for all other services. In addition to the services included in CICES classification, a new class, regulation of the spatial structure, was added. Three services have been proposed: connection of spaces, buffer disturbing uses, and provision of spatial complexity of the place (Table 3 ). This new class describes the way landscape configuration and context can condition other functions. On the one hand, these services are related to the capacity of landscape to adapt to change and ensure the provision of the other services for future generations. Connection of ecosystems and spatial complexity are preconditions for ecological resilience from an ecological point of view; whereas landscape complexity improves visual absorption capacity from a visual perceptual approach. On the other hand, services related to the regulation of spatial structure can be considered a precondition of cultural services. For instance, the connection between spaces influences the capacity of landscape to provide opportunities for sport and social encounters; spatial complexity may foster possibilities for exploration and learning; and buffering disturbing uses can contribute to the creation of friendlier environments for people and increase opportunities for 
Table 3. Description of the new services proposed for the classification of landscape services and their related concepts.

\begin{tabular}{|c|c|c|c|}
\hline Class & Group & Definition & Related Concepts \\
\hline \multirow[t]{3}{*}{ Daily Activities } & Place to live & $\begin{array}{l}\text { Provision of a space for residential location, a } \\
\text { home. }\end{array}$ & $\begin{array}{l}\text { Carrier functions (de Groot 2006); } \\
\text { Provision of space (Antrop et al. 2012) }\end{array}$ \\
\hline & Place to work & $\begin{array}{l}\text { Provision of open spaces or urbanized areas } \\
\text { where people develop their job. }\end{array}$ & $\begin{array}{l}\text { Carrier functions (de Groot 2006); } \\
\text { Provision of space (Antrop et al. 2012) }\end{array}$ \\
\hline & Place to move & $\begin{array}{l}\text { Provision of spatial communication. It is not } \\
\text { only related to transport networks but also to } \\
\text { open spaces that allow people to commute, } \\
\text { travel, or just access other services. }\end{array}$ & $\begin{array}{l}\text { Carrier functions (de Groot 2006); } \\
\text { Provision of space (Antrop et al. 2012) }\end{array}$ \\
\hline \multirow[t]{3}{*}{$\begin{array}{l}\text { Regulation of the } \\
\text { Spatial Structure }\end{array}$} & $\begin{array}{l}\text { Connection of } \\
\text { spaces }\end{array}$ & $\begin{array}{l}\text { Ability to facilitate ecological, visual, or } \\
\text { functional connectivity between different } \\
\text { areas. }\end{array}$ & Connectivity (Forman 1995) \\
\hline & $\begin{array}{l}\text { Buffer disturbing } \\
\text { use }\end{array}$ & $\begin{array}{l}\text { Ability to separate incompatible uses and } \\
\text { temper negative interactions from an } \\
\text { ecological or perceptual point of view. }\end{array}$ & $\begin{array}{l}\text { Buffer zone (Forman 1995, Bennet } \\
\text { and Mulongoy 2006) }\end{array}$ \\
\hline & $\begin{array}{l}\text { Provision of spatial } \\
\text { complexity }\end{array}$ & $\begin{array}{l}\text { Related to the degree of diversity and richness } \\
\text { of landscape elements that may improve } \\
\text { possibilities for exploration, resilience, and } \\
\text { visual absorption capacity. }\end{array}$ & $\begin{array}{l}\text { Diversity (Forman and Godron 1986), } \\
\text { heterogeneity (Forman 1995), and } \\
\text { complexity (Kaplan and Kaplan 1989, } \\
\text { Fry et al. 2009) }\end{array}$ \\
\hline \multirow[t]{2}{*}{ Health } & Physical health & $\begin{array}{l}\text { Contribution to the enhancement of physical } \\
\text { fitness by facilitating walking or other } \\
\text { alternative ways of transportation and the } \\
\text { practice of open air sports. }\end{array}$ & Physical health (TEEB 2010) \\
\hline & Mental health & $\begin{array}{l}\text { Opportunities to relax, recover from stress, } \\
\text { escape from our daily routine, find } \\
\text { tranquillity, be calm, or just fulfill our need of } \\
\text { mental space. }\end{array}$ & $\begin{array}{l}\text { Mental health (TEEB 2010), calm and } \\
\text { escapism (Research Box et al. 2009) }\end{array}$ \\
\hline \multirow[t]{2}{*}{ Enjoyment } & Passive enjoyment & $\begin{array}{l}\text { Enjoyment of attractive vistas, a quiet place } \\
\text { to read a book, the possibility of seeing } \\
\text { wildlife, or cultural heritage. }\end{array}$ & $\begin{array}{l}\text { Aesthetic appreciation, values (MEA } \\
\text { 2003, de Groot et al. 2010, Haines- } \\
\text { Young and Potschin 2010, TEEB } \\
\text { 2010), and heritage (Haines-Young } \\
\text { and Potschin 2010, de Groot et al. } \\
\text { 2010) }\end{array}$ \\
\hline & Active enjoyment & $\begin{array}{l}\text { Related to more dynamic ways of enjoying } \\
\text { spare time like opportunities for hiking, } \\
\text { climbing, gardening, hunting, fishing, or } \\
\text { providing a place for children to play. }\end{array}$ & $\begin{array}{l}\text { Recreation (Research Box et al. 2009, } \\
\text { de Groot et al. 2010, Haines-Young } \\
\text { and Potschin 2010, TEEB 2010), } \\
\text { tourism, and ecotourism (MEA 2003, } \\
\text { TEEB 2010) }\end{array}$ \\
\hline \multirow[t]{4}{*}{ Personal Fulfillment } & Way-finding & $\begin{array}{l}\text { Provision of cues that enhance our spatial } \\
\text { orientation, our sense of where we are, and } \\
\text { how to get where we are going. }\end{array}$ & $\begin{array}{l}\text { Orientation (Lynch 1960, Kaplan and } \\
\text { Kaplan 1998) }\end{array}$ \\
\hline & Scientific resources & $\begin{array}{l}\text { Source of research for a wide range of fields } \\
\text { such as history, geography, botany, ecology, } \\
\text { geology, or archaeology. }\end{array}$ & $\begin{array}{l}\text { Information and knowledge, } \\
\text { knowledge systems, and science (MEA } \\
\text { 2003, de Groot et al. 2010, Haines- } \\
\text { Young and Potschin 2010) }\end{array}$ \\
\hline & Didactic resources & $\begin{array}{l}\text { Opportunities to learn about rock formation, } \\
\text { flora and fauna species, past civilizations, or } \\
\text { traditional farming practices. }\end{array}$ & $\begin{array}{l}\text { Education, educational values, and } \\
\text { learning (MEA 2003, Research Box et } \\
\text { al. } 2009 \text {, de Groot et al. 2010) }\end{array}$ \\
\hline & Spiritual experience & $\begin{array}{l}\text { Provision of sacred places for religious } \\
\text { practices or sites connected to legends or } \\
\text { myths. }\end{array}$ & $\begin{array}{l}\text { Spiritual experience and religious } \\
\text { values or inspiration (MEA 2003, } \\
\text { Research Box et al. 2009, de Groot et } \\
\text { al. 2010, Haines-Young and Potschin } \\
\text { 2010, TEEB 2010) }\end{array}$ \\
\hline
\end{tabular}




\begin{tabular}{|c|c|c|c|}
\hline \multirow{4}{*}{ Social Fulfillment } & $\begin{array}{l}\text { Source of } \\
\text { inspiration }\end{array}$ & $\begin{array}{l}\text { Inspiration for art, literature, music, } \\
\text { architecture, cinema, or advertising. }\end{array}$ & $\begin{array}{l}\text { Inspiration for culture, art, and design } \\
\text { (MEA 2003, Research Box et al. 2009, } \\
\text { de Groot et al. 2010, TEEB 2010) }\end{array}$ \\
\hline & Social interactions & $\begin{array}{l}\text { Provision of social surroundings separate } \\
\text { from the two usual social environments of } \\
\text { home and the workplace that provide } \\
\text { opportunities for social encounters. }\end{array}$ & $\begin{array}{l}\text { Community activities, social relations } \\
\text { (MEA 2003, Haines-Young and } \\
\text { Potschin 2010) }\end{array}$ \\
\hline & Place identity & $\begin{array}{l}\text { Contribution to shaping of community } \\
\text { identity by providing icons and distinguishing } \\
\text { it from others. }\end{array}$ & $\begin{array}{l}\text { Sense of place, place identity, cultural } \\
\text { diversity, and cultural identity (MEA } \\
\text { 2003, Research Box et al. 2009, de } \\
\text { Groot et al. 2010, TEEB 2010) }\end{array}$ \\
\hline & Sense of continuity & $\begin{array}{l}\text { Provision of stable reference points through } \\
\text { the life course. }\end{array}$ & $\begin{array}{l}\text { Sense of history, sense of continuity } \\
\text { (Research Box et al. 2009) }\end{array}$ \\
\hline
\end{tabular}

enjoyment. Most of these aspects are already included in green infrastructure planning, but could also be taken into account during integrated landscape planning.

\section{Cultural and social life fulfillment services}

Cultural services are usually defined as all nonmaterial outputs that people obtain from the interaction with ecosystems. In the proposed framework, cultural services are classified in four classes, i.e., health, enjoyment, self/personal fulfillment, and social fulfillment, corresponding to the human dimensions (Table 3). This classification could be a useful basis for the incorporation of social oriented objectives in spatial plans. The interest in considering social benefits has been reflected in individual experiences or planning practices. For instance, the initiatives that seek improvement of public health through spatial planning, e.g., the Spatial Planning and Health Group in the United Kingdom (Tomlinson et al. 2013); the incorporation of recreational and educational criteria in planning, e.g., the experience of the recreational forests in the city of Zurich (Spiess et al. 2006); the Green to Play Project, Speelgroen, in Flanders that supports the creation of natural and flexible playgrounds, which trigger creativity, informal play, and learning (Franch and Van Roosendael 2012); and the central role traditionally attached to public space in urban planning to promote social relations and to create community (Katz 1994) are all good examples. The presented classification will provide the opportunity to integrate all these social issues that up to now have usually been considered separately.

\section{DISCUSSION}

The use of the term landscape is not new in the context of ecosystem services scientific literature. However, the landscape concept behind our proposed classification is different from the approaches in which landscape and ecosystem are considered synonymous concepts or different hierarchical levels (de Groot et al. 2010, Hermann et al 2011). According to the THE theory (Naveh and Lieberman 1994, Naveh 2000), it is not just a matter of scale that differentiates landscapes from ecosystems. Landscape is more than repeated ecosystems on $\mathrm{km}$-wide stretches and can be studied and managed at different scales. It is the human and holistic perspective that makes both concepts different.

With this integrated approach, three main principles have guided our proposed classification. First, it is assumed that the contribution of landscape to human well-being not only arises from the interaction of biotic and biotic processes, but also from human processes. According to the European Landscape Convention (Council of Europe 2000), landscape embraces all types of areas: natural, rural, urban, and peri-urban. This means that cultural landscapes or urbanized areas may also contribute to well-being, not just greenery. Second, there is an attempt to correct the imbalance between the material and immaterial benefits reflected in previous classifications. Thus, cultural services are not simply considered as amenities related to enjoyment (Haines-Young and Potschin 2010). They are considered as services that contribute to the fundamental needs related to social well-being, health, and personal realization. Third, the role of landscape configuration and context in regulating both ecological and perceptual processes is acknowledged. Thus, horizontal relations between ecosystems, together with the vertical relations within ecosystems, are considered responsible for the provision of landscape services.

This approach responds to Antrop' (2006) concerns, because he suggested that the concept of natural capital should be broadened to incorporate the role of human activity, i.e., culture, in shaping the landscape and not simply as a disturbance to the ecological balance. The landscape approach broadens the concept of sustainability. It assumes the contributions of both natural and cultural spatial patterns to the quality of life and situates economic, ecological, and socio-cultural dimensions at the same level. Hence, it can become an appropriate tool for incorporating sustainability principles in the planning, management, and design of cultural landscapes.

For this classification to become significant in the context of community-based landscape planning, a transdisciplinary approach and further research on the links between the supply of services and landscape characteristics is needed. Transdisciplinarity requires the involvement of stakeholders and the integration of different disciplines. Research must tackle not only the problem of a lack of information, but also the dispersion of knowledge. For this reason, the dialogue and exchange among different fields of knowledge, including natural and social sciences (Daniel et al. 2012), on the one hand, and between stakeholders and science, on the other hand, is required. This dialogue will improve knowledge within the structure-function-value chain and between chains (Termorshuizen and Opdam 2009). As well, the proposed set of services should be tested in different types of landscapes to verify that it is understandable by stakeholders. Furthermore, the 
existence of additional services that have not been taken into account, or the occurrence of systematic correlations among different services (double counting) should be checked.

With regard to the contribution to community-based landscape planning, the use of landscape services involves a change of focus. This means that the main goal of landscape planning needs to go beyond the optimal allocation of land use regarding biophysical and socio-cultural factors. It should seek to improve the capacity of landscape to deliver services that better meet human values (Selman 2006, Termorshuizen and Opdam 2009). Consequently, the use of landscape services oriented to planning practices will enhance the involvement of local actors in the different stages of planning, i.e., diagnosis, goal setting, planning options, design and implementation, and negotiation among different stakeholders. It is more meaningful to think about and to discuss this in terms of the benefits provided to the local community, e.g., food, timber, climate regulation, and recreation, than it is to think about or discuss this in terms of the physical elements of landscape, e.g., forest, wetland, and vineyards. In this sense, the proposed classification provides a framework for local actors that considers economic, ecological, and social benefits on the same level and which can be implemented in natural and cultural landscapes.

The proposed landscape services classification also demands other methods and techniques to map the services and make them spatially explicit. On the one hand, the assumption of landscape as a whole involves mapping landscape services based on landscape patterns, i.e., landscape types, instead of land cover (Burkhard et al. 2012). This approach is consistent with previous authors like Blaschke (2006) or de Groot et al. (2012), who suggested that the provision of certain services may depend on the association of different types of land cover and their spatial arrangement, and that sometimes context can be more important than content. On the other hand, cultural services are not possible to get from existing data and cannot be approached from an ecosystem perspective. Thus, public consultation should be part of the identification and assessment of landscape services. In this way, participatory social value methodologies (Fagerholm et al. 2012) and community-based processes in general can play an important role. They can provide generic knowledge and particularly area specific information regarding the connection between landscape patterns and services (Steingröver et al. 2012). As well, they can give an insight into benefits that different groups of actors perceive from the same landscape.

\section{CONCLUSION}

The ecosystem services framework is a useful tool to integrate sustainability principles in decision-making processes. However, it mainly focuses on natural ecosystems or greenery within anthropogenic areas and their associated production and regulation functions. The extension of the ecosystem services approach to landscape involves the consideration of spatial patterns and context. It also implies assuming human actions as part of the processes, which, together with abiotic and biotic factors, shape the landscape. The classification proposed adapts the CICES classification to the concept of landscape services and considers landscape from an integrated and transdisciplinary approach. One of the consequences of this concept is the integration of additional services related to the provision of space. Another consequence is the consideration of the regulation of ecological and perceptual processes based on the spatial configuration of landscape. Finally, this landscape services approach rearranges cultural services according to the ways landscapes contribute to well-being.

This classification complies with the three prerequisites established for a landscape service typology. These prerequisites are related to the balance between well-being gains derived from nature and from the interaction of nature with humans; material and immaterial benefits derived from landscape; and the vertical and horizontal relations of landscape. Therefore, our classification offers added value for its application in landscape planning above other proposed classifications. The application of this classification will require the identification of landscape services based on spatial landscape patterns instead of land-cover types and will require an increased use of participatory techniques to involve stakeholders.

Responses to this article can be read online at: http://www.ecologyandsociety.org/issues/responses. $\mathrm{php} / 6251$

\section{Acknowledgments:}

This work was developed thanks to the support of UPV mobility grants for lecturers and ECO2011-27369 Research Project.

\section{LITERATURE CITED}

Alkire, S. 2002. Dimensions of human development. World Development 30(2):181-205.

Andrewartha, H. G. 1971. Introduction to the study of animal populations. Second edition. University of Chicago Press, Chicago, Illinois, USA. http://dx.doi.org/10.1007/978-1-4613-3324-1

Antrop, M. 2000. Background concepts for integrated landscape analysis. Agriculture, Ecosystems and Environment 77:17-28. http://dx.doi.org/10.1016/S0167-8809(99)00089-4

Antrop, M. 2003. The role of cultural values in modern landscapes. The Flemish example. Pages 91-108 in H. Palang and G. Fry, editors. Landscape interfaces. Cultural heritage in changing landscapes. Kluwer Academic, Dordrecht, Germany. http://dx. doi.org/10.1007/978-94-017-0189-1 6

Antrop, M. 2006. Sustainable landscapes: contradiction, fiction, or utopia? Landscape and Urban Planning 75:187-197. http://dx. doi.org/10.1016/j.landurbplan.2005.02.014

Antrop, M., M. Sevenant, C. Tagliaferro, V. Van Eetvelde, and F. Witlox. 2012. Setting a framework for valuing the multifunctional landscape and its multiple perceptions. Pages 23-52 in C. M. van der Heide and W. Heijman, editors. The economic value of landscapes. Routledge, Oxford, UK.

Bennet, G., and K. J. Mulongoy. 2006. Review of experience with ecological networks, corridors and buffer zones. CBD Technical Series No. 23. Secretariat of the Convention on Biological Diversity, Montreal, Quebec, Canada. [online] URL: https:// www.cbd.int/doc/publications/cbd-ts-23.pdf 
Bernbaum, E. 1991. The Himalayas, realm of the sacred. Pages 107-119 in J. A. Swan, editor. The power of place: sacred ground in natural and human environments. Quest, Wheaton, Illinois, USA.

Björklund, J., K. E. Limburg, and T. Rydberg. 1999. Impact of production intensity on the ability of the agricultural landscape to generate ecosystem services: an example from Sweden. Ecological Economics 29: 269-291. http://dx.doi.org/10.1016/ $\underline{\text { S0921-8009(99)00014-2 }}$

Blaschke, T. 2006. The role of the spatial dimension within the framework of sustainable landscapes and natural capital. Landscape and Urban Planning 75:198-226. http://dx.doi. org/10.1016/j.landurbplan.2005.02.013

Bolliger, J., and F. Kienast. 2010. Landscape functions in a changing environment. Landscape Online 21:1-5. http://dx.doi. org/10.3097/LO.201021

Bos, E., P. van der Jagt, and W. Timmermans. 2008. The landscape as a source of inspiration for painters: paintings as a source of inspiration for land development? WIT Transactions on Ecology and the Environment 115:45-51. http://dx.doi.org/10.2495/ $\underline{\mathrm{ST} 080051}$

Brown, G. 2004. Mapping spatial attributes in survey research for natural resource management: methods and applications. Society and Natural Resources 18:17-39. http://dx.doi.org/10.1080/0894$\underline{1920590881853}$

Brundtland, G. 1987. Our common future (The Brundtland report). World Commission on Environment and Development. Oxford University Press, Oxford, UK.

Burkhard, B., F. Kroll, S. Nedkov, and F. Müller. 2012. Mapping ecosystem service supply, demand and budgets. Ecological Indicators 21:17-29. http://dx.doi.org/10.1016/j.ecolind.2011.06.019

Costanza, R., R. d'Arge, R. de Groot, S. Farber, M. Grasso, B. Hannon, K. Limburg, S. Naeem, R. V. O’Neill, J. Paruelo, R. G. Raskin, P. Sutton, and M. van den Belt. 1997. The value of the world's ecosystem services and natural capital. Nature 387:253-260. http://dx.doi.org/10.1038/387253a0

Cottrell, S. P., J. Lengkeek, and R. van Marwijk. 2005. Typology of recreation experiences: application in a Dutch forest service monitoring survey. Managing Leisure 10(1):54-72. http://dx.doi. org/10.1080/13606710500086827

Council of Europe. 2000. Landscape European convention. Council of Europe, Florence, Italy.

Council of Europe. 2005. Council of Europe framework convention on the value of cultural heritage for society. Council of Europe, Florence, Italy. [online] URL: http://conventions.coe.int/Treaty/ EN/Treaties/Html/199.htm

Daily, G. C., editor. 1997. Nature's services: societal dependence on natural ecosystems. Island, Washington, D.C., USA.

Daniel, T. C., A. Muhar, A. Arnberger, O. Aznar, J. W. Boyd, K. M. A. Chan, R. Costanza, T. Elmqvist, C. G. Flint, P. H. Gobster, A. Grêt-Regamey, R. Lave, S. Muhar, M. Penker, R. G. Ribe, T. Schauppenlehner, T. Sikor, I. Soloviy, M. Spierenburg, K. Taczanowska, J. Tam, and A. von der Dunk. 2012. Contributions of cultural services to the ecosystem services agenda. Proceedings of the National Academy of Sciences 109(23):8812-8819. http:// dx.doi.org/10.1073/pnas.1114773109

de Groot, R. S. 1992. Functions of nature: evaluation of nature in environmental planning, management and decision making. Wolters-Noordhoff, Amsterdam, the Netherlands.

de Groot, R. S. 2006. Function-analysis and valuation as a tool to assess land use conflicts in planning for sustainable, multifunctional landscapes. Landscape and Urban Planning 75:175-186. http://dx.doi.org/10.1016/j.landurbplan.2005.02.016

de Groot, R. S., M. A. Wilson, and R. M. J. Boumans. 2002. A typology for the classification, description and valuation of ecosystem functions, goods and services. Ecological Economics 41(3):393-408. http://dx.doi.org/10.1016/S0921-8009(02)00089-7

de Groot, R. S., R. Alkemade, L. Braat, L. Hein, and L. Willemen. 2010. Challenges in integrating the concept of ecosystem services and values in landscape planning, management and decision making. Ecological Complexity 7:260-272. http://dx.doi. org/10.1016/j.ecocom.2009.10.006

Dobbs, C., F. J. Escobedo, and W. C. Zipperer. 2011. A framework for developing urban forest ecosystem services and goods indicators. Landscape and Urban Planning 99:196-206. http://dx. doi.org/10.1016/j.landurbplan.2010.11.004

Fagerholm, N., N. Käyhkö, F. Ndumbaro, and M. Khamis. 2012. Community stakeholders' knowledge in landscape assessments mapping indicators for landscape services. Ecological Indicators 18:421:433. http://dx.doi.org/10.1016/j.ecolind.2011.12.004

Forman, R. T. T. 1995. Land mosaics: the ecology of landscapes and regions. Cambridge University Press, Cambridge, UK.

Forman, R. T. T., and M. Godron. 1986. Landscape ecology. Wiley and Sons, New York, New York, USA.

Franch, M., and D. Van Roosendael. 2012. Project "green to play." Paisea 22:72-78.

Fry, G., M. S. Tveit, Å. Ode, and M. D. Velarde, 2009. The ecology of visual landscapes: exploring the conceptual common ground of visual and ecological landscape indicators. Ecological Indicators 9:933-947. http://dx.doi.org/10.1016/j.ecolind.2008.11.008

Gómez-Baggethun, E., and D. N. Barton. 2013. Classifying and valuing ecosystem services for urban planning. Ecological Economics 86:235-245. http://dx.doi.org/10.1016/j.ecolecon.2012.08.019

Graham, H., R. Mason, and A. Newman. 2009. Literature review: historic environment, sense of place, and social capital. English Heritage, London, UK. [online] URL: http://hc.english-heritage. org.uk/content/pub/sense of place lit review web1.pdf

Haines-Young, R. H., and M. B. Potschin. 2010. Proposal for a common international classification of ecosystem goods and services (CICES) for integrated environmental and economic accounting (VI). Report to the European Environment Agency. Department of Economic and Social Affairs Statistics Division, United Nations, Nottingham, UK.

Hermann, A., S. Schleifer, and T. Wrbka. 2011. The concept of ecosystem services regarding landscape research: a review. Living Reviews in Landscape Research 5:1-37. http://dx.doi.org/10.12942/ $\underline{1 r l r-2011-1}$ 
Hull, R. B., IV, M. Lam, and G. Vigo. 1994. Place identity: symbols of self in the urban fabric. Landscape and Urban Planning 28:109-120. http://dx.doi.org/10.1016/0169-2046(94)90001-9

Jackson, L. E. 2003. The relationship of urban design to human health and condition. Landscape and Urban Planning 64:191-200. http://dx.doi.org/10.1016/S0169-2046(02)00230-X

Kaplan, R., and S. Kaplan. 1989. The experience of nature: a psychological perspective. Cambridge University Press, Cambridge, UK.

Kaplan, R., S. Kaplan, and R. L. Ryan. 1998. With people in mind. Design and management of everyday nature. Island, Washington, D.C., USA.

Katz, P. 1994. The new urbanism: toward an architecture of community. McGraw-Hill, New York, New York, USA.

Korpela, K. M., T. Hartig, F. G. Kaiser, and U. Fuhrer. 2001. Restorative experience and self-regulation in favourite places. Environment and Behavior 33:572-589. http://dx.doi. org/10.1177/00139160121973133

Kim, J., and R. Kaplan. 2004. Physical and psychological factors in sense of community. New urbanist Kentlands and nearby Orchard Village. Environment and Behaviour 36:313-340. http:// dx.doi.org/10.1177/0013916503260236

Kuo, F. E. 2003. The role of arboriculture in a healthy social ecology. Journal of Arboriculture 29(3):148-155. [online] URL: http://archive.treelink.org/joa/2003/may/04Kuo.pdf

Lamarque, P., F. Quétier, and S. Lavorel. 2011. The diversity of the ecosystem services concept and its implications for their assessment and management. Comptes Rendus Biologies 334:441-449. http://dx.doi.org/10.1016/j.crvi.2010.11.007

Lindemann-Matthies, P. 2005. 'Loveable' mammals and 'lifeless' plants: how children's interest in common local organisms can be enhanced through observation of nature. International Journal of Science Education 27:655-677. http://dx.doi.org/10.1080/095006$\underline{90500038116}$

Lynch, K. 1960. The image of the city. M. I. T. Press, Cambridge, Massachusetts, USA.

Macfadyen, M., S. A. Cunningham, A. C. Costamagna, and N. A. Schellhorn. 2012. Managing ecosystem services and biodiversity conservation in agricultural landscapes: are the solutions the same? Journal of Applied Ecology 49:690-694. http:// dx.doi.org/10.1111/j.1365-2664.2012.02132.x

Maslow, A. H. 1970. Motivation and personality. Second edition. Harper and Row, New York, New York, USA.

Matsuoka, R. H., and R. Kaplan. 2008. People needs in the urban landscape: analysis of Landscape and Urban Planning contributions. Landscape and Urban Planning 84:7-19. http://dx. doi.org/10.1016/j.landurbplan.2007.09.009

Millennium Ecosystem Assessment (MEA). 2003. Ecosystems and human well-being: a framework for assessment. Island, Washington, D.C., USA. [online] URL: http://www.maweb.org/ en/Framework.aspx
Millennium Ecosystem Assessment (MEA). 2005. Ecosystems and human well-being: biodiversity synthesis. Island, Washington, D.C., USA. [online] URL: http://www.maweb.org/documents/ document.354.aspx.pdf

Narayan, D., R. Patel, K. Schafft, A. Rademacher, and S. KochSchulte. 2000. Can anyone hear us: voices of the poor. World Bank, New York, New York, USA.

Naveh, Z. 2000. What is holistic landscape ecology? A conceptual introduction. Landscape and Urban Planning 50:7-26. http://dx. doi.org/10.1016/S0169-2046(00)00077-3

Naveh, Z., and A. S. Lieberman. 1994. Landscape ecology: theory and applications. Second edition. Springer, New York, New York, USA.

Nohl, W. 2001. Sustainable landscape use and aesthetic perception - preliminary reflections on future landscape aesthetics. Landscape and Urban Planning 54:223-237. http://dx. doi.org/10.1016/S0169-2046(01)00138-4

Norton, L. R., H. Inwood, A. Crowe, and A. Baker. 2012. Trialling a method to quantify the 'cultural services' of the English landscape using countryside survey data. Land Use Policy 29:449-455. http://dx.doi.org/10.1016/j.landusepol.2011.09.002

Oldenburg, R. 2000. Celebrating the third place: inspiring stories about the "great good places" at the heart of our communities. Marlowe and Co., New York, New York, USA.

Pendola, R., and S. Gen. 2008. Does "Main Street" promote sense of community? A comparison of San Francisco neighborhoods. Environment and Behavior 40(4):545-574. http://dx.doi. org/10.1177/0013916507301399

Research Box, Land Use Consultants, and R. Minter. 2009. Capturing the cultural services and experiential qualities of landscape. Natural England Commissioned Report NECR024. Natural England, Cheltenham, UK. [online] URL: http:// publications.naturalengland.org.uk/publication/48001

Rokeach, M. 1973. The nature of human values. Free Press, New York, New York, USA.

Selman, P. 2006. Planning at the landscape scale. Routledge, Oxford, UK.

Shafer, C. S., B. K. Lee, and S. Turner. 2000. A tale of three greenway trails: user perceptions related to quality of life. Landscape and Urban Planning 49:163-178. http://dx.doi. org/10.1016/S0169-2046(00)00057-8

Spiess, H., M. Mönnecke, K. Wasem, and D. Kümin. 2006. Local recreational areas: accounting for peoples' needs in the development and selection of planning instruments. Pages 253-258 in D. Siegrist, C. Clivaz, M. Hunziker, and S. Iten, editors. Exploring the nature of management. Proceedings of the third international conference on monitoring and management of visitor flows in recreational and protected areas. University of Applied Sciences Rapperswil, Rapperswil-Jona, Switzerland.

Steingröver, E. G., W. Geertsema, and W. K. R. E. van Wingerden. 2010. Designing agricultural landscapes for natural pest control: a transdisciplinary approach in the Hoeksche Waard (The 
Netherlands). Landscape Ecology 25:825-838. http://dx.doi. org/10.1007/s10980-010-9489-7

Summers, J. K., L. M. Smith, J. L. Case, and R. A. Linthurst. 2012. A review of the elements of human well-being with an emphasis on the contribution of ecosystem services. $A M B I O$ 41:327-340. http://dx.doi.org/10.1007/s13280-012-0256-7

Termorshuizen, J. W., and P. Opdam. 2009. Landscape services as a bridge between landscape ecology and sustainable development. Landscape Ecology 24:1037-1052. http://dx.doi. org/10.1007/s10980-008-9314-8

The Economics of Ecosystems and Biodiversity (TEEB). 2010. Mainstreaming the economics of nature: a synthesis of the approach, conclusions and recommendations of TEEB. UNEP TEEB, Geneva, Switzerland.

Tomlinson, P., S. Hewitt, and N. Blackshaw. 2013. Joining up health and planning: how joint strategic needs assessment (JSNA) can inform health and wellbeing strategies and spatial planning. Perspectives in Public Health 133:254-262. http://dx.doi. org/10.1177/1757913913488331

Tress, B., and G. Tress. 2001. Capitalising on multiplicity: a transdisciplinary systems approach to landscape research. Landscape and Urban Planning 57:143:157. http://dx.doi. org/10.1016/S0169-2046(01)00200-6

Tzoulas, K., and K. Greening. 2011. Urban ecology and human health. Pages 263-271 in J. Niemelä, J. H. Breuste, G. Guntenspergen, N. E. McIntyre, and T. Elmqvist, editors. Urban Ecology. Patterns, processes and applications. Oxford University Press, Oxford, UK. http://dx.doi.org/10.1093/acprof: oso/9780199563562.003.0032

Ulrich, R, S. 1984. View through a window may influence recovery from surgery. Science 224:420-421. http://dx.doi.org/10.1126/ science. 6143402

Ulrich, R. S. 1997. A theory of supportive design for healthcare facilities. Journal of Healthcare Design 9:3-7.

United Nations Educational, Scientific and Cultural Organization (UNESCO). Convention for the safeguarding of intangible cultural heritage. UNESCO, Paris, France. [online] URL: http://www.unesco.org/culture/ich/index.php?pg=00006

Wallace, K. J. 2007. Classification of ecosystem services: problems and solutions. Biological conservation 139:235-246. http://dx.doi. org/10.1016/j.biocon.2007.07.015

Wallace, K. J. 2012. Values: drivers for planning biodiversity management. Environmental Science and Policy 17:1-11. http:// dx.doi.org/10.1016/j.envsci.2011.12.001

Ward Thompson, C., J. Roe, P. Aspinall, R. Mitchell, A. Clow, and D. Miller. More green space is linked to less stress in deprived communities: evidence from salivary cortisol patterns. 2012. Landscape and Urban Planning 105:221-229. http://dx.doi. org/10.1016/j.landurbplan.2011.12.015 